Original research article

\title{
Leadership style and its influence on employee identification with the organisation: A study from a Czech hospital
}

\author{
Martina Bednářová ${ }^{1 *}$, Miloslava Hiršová ${ }^{2}$, Lenka Komárková ${ }^{3}$ \\ ${ }^{1}$ University of Economics, Prague, Faculty of Management, Department of Management, Jindřichưv Hradec, Czech Republic \\ ${ }^{2}$ University of Economics, Prague, Faculty of Management, Department of Social Sciences, Jindrichův Hradec, Czech Republic \\ ${ }^{3}$ University of Economics, Prague, Faculty of Management, Department of Exact Methods, Jindřichüv Hradec, Czech Republic
}

\begin{abstract}
Leaders are in daily contact with subordinate employees, and through their leadership style they affect the day-to-day running of the organisation. Using the transformational leadership theory, this paper aims to explore the impact of leadership styles on organisational identification, i.e. on an important and complex variable that plays a key role in organisational effectiveness. We asked a sample of nurses from a medium-sized regional hospital to assess the prevailing leadership style of their head nurses along with the degree of their own identification with the hospital. The quantitative research design based on a questionnaire survey was applied in this study. The first part consisted of the Multifactor Leadership Questionnaire, which measures the applied leadership style and its components. The second part was formed by the Mael and Ashforth scale, which assesses the organisational identification of the employees. The relationship between the chosen variables was assessed by multiple linear regression with the inclusion of the employment length and department type as control variables. Our results show that the transactional style slightly prevails in this hospital, although only the transformational style and two of its components have an impact on the degree of organisational identification.
\end{abstract}

Keywords: Healthcare management; Leadership; Organisational identification

\section{Introduction}

Healthcare organisations in Czechia are under pressure to provide high-quality services. One of the major problems they face is a severe shortage of nurses. Nursing jobs are undoubtedly among those that are the most demanding, challenging and highly stressful (Gulavani and Shinde, 2014; Healy and Tyrrell, 2011). It is widely recognised that this profession is often the source of a strong emotional burden associated not only with everyday contact with human suffering and pain but also with the lack of job control or social support (AbuAlRub, 2004). It is no surprise that the number of nurses affected by burnout syndrome is increasing year on year (Bakker et al., 2005; Holdren et al., 2015), and unsurprisingly there is a considerable turnover rate in the profession.

Since the nursing profession usually requires lifelong learning, mostly at the expense of the employer, it is in the interest of healthcare providers to prevent the turnover of staff. This can be achieved in various ways, but we believe the best is to strengthen the identification of employees with their organisation (Cole and Bruch, 2006; Cooper and Thatcher, 2010; Fuchs, 2012; Lee et al., 2015). Organisational identification is a highly complex process involving many variables. Since the environment of healthcare organisations is usually associated with specific forms of management that are historically given, we focus on identifying the role of leadership in these processes.

Leadership creates a key component of organisational success. Creating new conditions, rules, strategies and essentially defining future changes play the primary role in leadership (Delić et al., 2017). As Glamuzina (2015) stated in her study, leadership is a significant competitiveness factor in many organisations.

\section{Theoretical background}

The beginnings of scientific research focusing on leadership can be dated back to more than a hundred years ago (Northouse, 2016). Most of us use the term leadership in various situations, although the meaning we attach to it differs. Stogdill (1974) stated that the number of definitions of leadership is almost identical to the number of people who have attempted to define it. By general definition, leadership is "The ability to inspire confidence and support among the people who are needed to achieve organisational goals" (DuBrin, 2016, p. 2).

However, the focus of leadership research lies not on its definition, but in its role in organisational performance (Bass, 1985; Bass et al., 2003; Chandra and Priyono, 2016; Karadağ, 2015). The central interest in this field of study lies in the role of leadership styles, which are the patterns of beliefs, values

\footnotetext{
* Author for correspondence: Martina Bednářová, University of Economics, Prague, Faculty of Management, Department of Management, Jarošovská 1117/II, 37701 Jindřichův Hradec, Czech Republic; e-mail: martina.bednarova@vse.cz http://doi.org/10.32725/kont.2019.035 
and behaviour shown by leaders. A comprehensive overview of leadership styles is provided by Anderson and Sun (2017). They emphasise the increase in the number of adjectives used to describe leadership styles since 2000 and analyse nine of them. Nonetheless, they admit that the leading role within this area is still the transformational and transactional style. This can be confirmed by the immense amount of research based on these two styles (e.g. Failla and Stichler, 2008; Lowe and Gardner, 2000; Morsiani et al., 2017; Wang et al., 2001).

The theoretical concept of transformational leadership, which is the core of this study, was formulated by Burns (1978). Burns (1978) distinguished between two types of leadership (transactional and transformational), which he considers to be mutually exclusive. Bass (1985) later developed the concept of these two types especially in terms of their complementary character. In contrary to Burns's understanding, these two styles can be used by leaders at the same moment. Transactional leadership is based on setting clear expectations, providing feedback, controlling, rewarding and correcting followers' behaviour (Burns, 1978). Transactional leaders are represented by their focus on day-to-day operations (Northouse, 2016). Transformational leadership builds on a complementary relationship between leader and subordinate. According to Huber (2010, p. 17), a transformational leader is defined as "a leader who motivates followers to perform to their full potential over time by influencing a change in perceptions and by providing a sense of direction".

Transformational leadership uses five substyles: (a) idealised influence (attributed) concerns the leader's charisma and whether they are perceived as confident and strong (Antonakis et al., 2003); (b) idealised influence (behaviour) corresponds to unified behaviour, which shows that the leader believes in themselves and acts in accordance with the values and purpose of the mission; (c) inspirational motivation is aimed at empowering and motivating subordinates; an inspiring leader is optimistic and shows faith in the fulfilment of the goals and the vision (Avolio and Bass, 2004); (d) intellectual stimulation where the leader acquires his/her own ideas from their followers, engages them and leads them to find new procedures (Kirkbride, 2006); (e) individual consideration where the leader knows his/ her followers and takes into account their strengths, reserves and needs, and thus increases their sense of importance and irreplaceability (Avolio and Bass, 2004).

Transactional leadership is composed of two substyles: (a) contingent reward where the leader's behaviour is focused on clarifying the role and task requirements (Antonakis et al., 2003) and provides meaningful rewards based on task completion (Andrews et al., 2012); (b) management-by-exception (active) where active leaders try to avoid a serious problem in advance, and set clear rules and alerts based on regular checks (Judge and Piccolo, 2004).

As the last component of the questionnaire measuring leadership styles is passive avoidant leadership, we also consider it in our results. It is composed of two substyles: (a) management-by-exception (passive) where passive leaders act only when the problem has already occurred; (b) laissez-faire, which is characterised by the absence of leadership and is reflected in the avoidance of responsibility (Alloubani, 2016).

Transactional and transformational views on leadership in organisations are leader focused and address the specific behaviour of leaders and the impact on the organisation and people inside the organisation (Tummers and Knies, 2013). The impact mostly concerns organisational performance and effectiveness (Avolio et al., 2009; Dinh et al., 2013; Northouse, 2016) although there are many studies aimed at specific fac- tors, such as the ability of organisational learning (Yukl, 2008) and nurse innovation behaviour (Weng et al., 2015). This approach is one of the most influential theories guiding healthcare leadership research (Gilmartin and D'Aunno, 2007; Wong et al., 2013).

In our opinion, the relation between leadership and organisational performance is not direct but works through influencing components of organisational behaviour, such as the motivation of employees, their commitment, creativity and, as a consequence, the level of the employees' identification with the organisation.

The theme of organisational identification is rather new and interest in it is closely related to issues of identity. Identity provides the answer to the questions "Who am I?" and "Who are we?" An individual's identity consists of his/her personal identity (qualities, abilities, interests, physical attributes) and social identity (reflecting the social categories to which an individual feels they belong). Personal identity is a unique way of how people perceive themselves as individuals, and social identity comes from an individual's view of their membership of a social group (Asforth et al., 2008). Albert and Whetten (1985) argued that organisational identity, like the identity of an individual, consists of shared values that help the processes of sense-giving and decision-making in key situations, especially those where the individual or organisation stands at a crossroads.

One of the first descriptions of organisational identification was developed by Patchen (1970). He stated three components of identification with an organisation: a perception of shared characteristics with the members of the organisation, a feeling of solidarity with the organisation and the support of the organisation (Moksness, 2014). Ashforth and Mael (1989) take the identification with the organisation as a specific form of social identification and define it as a consciousness of unity with the organisation and the consciousness of belonging to it. Dutton et al. (1994) define identification with the organisation as a cognitive link between the worker and his/her organisation, specifically as a degree of consistency between the attributes by which the worker defines themselves and the attributes which define the organisation.

Research studies have confirmed the significant impact of organisational identification on individual attitudes and behaviour in organisations. When considering employee satisfaction - a significant factor influencing employee performance - employees who identify with the organisation tend to perceive their work as meaningful and satisfying (Lee et al., 2015). Employees strongly identifying with the organisation are more willing to behave in accordance with the organisation's goals (Haslam and Ellemers, 2005). The current level of knowledge confirms that the level of organisational identification affects the performance of the employees and thus has an important impact on the overall performance of the organisation (Fiol and O'Connor, 2005; Haslam and Ellemers, 2005; Millward and Postmes, 2010; Tyler and Blader, 2001).

According to meta-analyses (Haslam, 2004; Haslam and Ellemers, 2005; Riketta, 2005; Riketta and Van Dick, 2005), the degree of organisational identification is associated with organisational processes including cooperation, employees' efforts, participation and beneficial decision making. Although the issues of transformational and transactional leadership and their impact on organisational behaviour are a frequent subject of research abroad, in Czechia we can only find sporadic studies of these issues (Procházka and Vaculík, 2015). Regarding the field of healthcare, we have not been able to find any studies on this subject for the Central and Eastern Europe (CEE) region. 
There is a general awareness that in the CEE region healthcare management still retains many elements of the old system of the Austro-Hungarian Empire, which is based on the authoritative power of head physicians. Nurse leaders are often perceived only as assistants following the physicians' orders and their social status is lower (Jarošová, 2006). It can be generally assumed that head nurses are more in touch with nursing staff and thus, compared to physicians, they have a greater impact on the level of nurses' identification with the organisation. Therefore, we focus on this specific segment of healthcare employees. The aim of our study is to contribute to the level of knowledge in this field by providing the answers to the following research questions:

RQ1: Which leadership style has an impact on the employees' degree of organisational identification?

RQ2: Which components of this style play the key role in the degree of organisational identification?

\section{Materials and methods}

The study focused on one hospital, which was selected on the basis of the willingness of the hospital management to participate in the research. To preserve the anonymity of the hospital, its size is only presented through number-of-beds intervals. It is a medium-sized (300-500 beds) Czech hospital with less than 1000 employees. In terms of its size, it is the most common type of hospital in Czechia. The hospital has the legal form of a joint-stock company owned by regional self-government (the major type of owner in Czechia) and provides inpatient and outpatient care, as well as chronic care beds. The chosen hospital has been profitable in recent years and is one of the major employers in the district. Our study focused on the non-medical healthcare staff, particularly nurses.

The research study is based on the questionnaire survey that was conducted in autumn of 2017. Departments with less than 4 nurses did not participate in the study. The questionnaire form was distributed to all nurses from departments included in our study. The nurses were asked to rate the leadership style of their direct superior (head nurse) and their own degree of identification with the hospital. Individual leadership (sub)styles were identified using the Multifactor Leadership Questionnaire (MLQ) by Avolio and Bass (2004), which is a worldwide validated instrument for measuring leadership style. The MLQ consists of 45 items in total and 36 items from the questionnaire focus on specific leadership (sub)styles. Five substyles represent transformational leadership, two substyles are aimed at transactional leadership and two substyles at the passive avoidant leadership style. All the nine leadership substyles are expressed by four items. Each item is rated on a five-point Likert scale, ranging from 0 (not at all) to 4 (frequently if not always). The degree of staff identification with the hospital was assessed by the means of five questions based on the Mael and Ashforth (1992) organisational identification scale with a four-point rating scale: -2 strongly disagree, -1 disagree, 1 agree, 2 strongly agree.

The survey was anonymous, and the 292 nurses were asked to fill in only the length of their employment in the hospital using pre-specified intervals and the department they were working in. The employment length and department type (inpatient ward or outpatient ward) were assessed as control variables with possible impacts on the organisational identification degree. The questionnaire was completed by 136 respondents and the return rate was $46.6 \%$.

Standard statistical methods were used to evaluate the questionnaire data. Specifically, these were descriptive statistics, two-sample $t$-tests, and multiple linear regression. The analysis was conducted in the statistical software R (R Core Team, 2018).

\section{Results and discussion}

The results of the questionnaire are summarised in Table 1 and Table 2. More than half of the respondents had worked in the hospital for more than nine years. The average values of MLQ show that the passive style is perceived by nurses as the least frequent. Transformational and transactional styles are applied together (Table 1), which corresponds to the results of our pilot study (Bednářová and Komárková, 2017). The mentioned study targeted the head nurses' leadership styles as perceived by themselves, not by their subordinates.

With the exception of the passive avoidant style, the differences between the evaluation of individual substyles are minimal. In particular, there is a slight predominance of: (1) management by exception (active) as part of the transactional style, (2) idealised influence (behaviour), (3) intellectual stimulation, both belonging to the transformational leadership style. The order is similar to that found in the pilot study mentioned above, but the average values obtained are now lower. Differences in leader self-assessment and subordinate ratings are common and may be both lower and higher. Interesting-

Table 1. Evaluation of leadership substyles of healthcare managers by respondents and according to the department type (inpatient ward or outpatient ward) including results of means comparison by two-sample Student's t-test

\begin{tabular}{|c|c|c|c|c|c|c|c|c|}
\hline \multirow[b]{2}{*}{ Leadership style } & \multicolumn{2}{|c|}{ Total } & \multicolumn{2}{|c|}{ Inpatient } & \multicolumn{2}{|c|}{ Outpatient } & \multicolumn{2}{|c|}{ Comparison } \\
\hline & Mean & $S D$ & Mean & $S D$ & Mean & $S D$ & Diff & $p$-value \\
\hline \multicolumn{9}{|l|}{ Transformational leadership } \\
\hline Idealised influence (attributed) & 2.45 & 0.98 & 2.37 & 1.00 & 2.69 & 0.86 & -0.32 & 0.093 \\
\hline Idealised influence (behaviour) & 2.66 & 0.85 & 2.56 & 0.84 & 2.97 & 0.84 & -0.41 & 0.013 \\
\hline Inspirational motivation & 2.57 & 0.88 & 2.42 & 0.89 & 3.00 & 0.70 & -0.58 & $<0.001$ \\
\hline Intellectual stimulation & 2.62 & 0.91 & 2.55 & 0.94 & 2.83 & 0.80 & -0.28 & 0.115 \\
\hline Individual consideration & 2.54 & 1.05 & 2.52 & 1.05 & 2.59 & 1.08 & -0.07 & 0.740 \\
\hline \multicolumn{9}{|l|}{ Transactional leadership } \\
\hline Contingent reward & 2.59 & 0.93 & 2.48 & 0.94 & 2.94 & 0.85 & -0.46 & 0.012 \\
\hline Management-by-except. (active) & 2.73 & 0.82 & 2.71 & 0.84 & 2.79 & 0.76 & -0.08 & 0.638 \\
\hline \multicolumn{9}{|l|}{ Passive avoidant leadership } \\
\hline Management-by-except. (passive) & 1.58 & 0.84 & 1.52 & 0.85 & 1.75 & 0.80 & -0.23 & 0.160 \\
\hline Laissez-faire & 0.99 & 1.05 & 1.04 & 1.06 & 0.85 & 1.02 & 0.19 & 0.363 \\
\hline
\end{tabular}


ly, this discrepancy in assessment can have some impacts on leadership outcomes. One of them concerns the satisfaction of the subordinates: the lower self-assessment of the leader compared to the subordinate rating correlates with the greater satisfaction of the subordinates with the style of leadership and vice versa (Andrews et al., 2012).

All assessed leadership substyles are more intensively perceived by the respondents in outpatient wards. The only exception is the laissez-faire style, where the average for this type of wards is slightly lower. However, the statistically significant difference was only found in three substyles; two of them belonged to the transformational style - namely idealised influence (behaviour) and inspirational motivation. Contingent reward was the only differing transactional substyle.
The degree of respondents' identification with the hospital reached an average of 0.25 on the scale $[-2,2]$. The highest degree was in the case of respondents working in the hospital in the range of 3 to 9 years (Table 2). The dependence of the identification degree on leadership styles has been assessed by multiple linear regression. The model included employment length and department type (outpatient wards include departments with no beds and departments of medical complement) as control variables. Employment length is represented by two dummy variables with the reference category "Short"; department type is represented by one dummy variable with the reference category "Outpatient ward".

Table 2. Assessment of the identification degree of nurses depending on their employment length and according to the department type (inpatient ward or outpatient ward)

\begin{tabular}{|c|c|c|c|c|c|c|c|c|c|}
\hline & \multicolumn{3}{|c|}{ Inpatient ward } & \multicolumn{3}{|c|}{ Outpatient ward } & \multicolumn{3}{|c|}{ Total } \\
\hline Employment & Freq. & Mean & $S D$ & Freq. & Mean & $S D$ & Freq. & Mean & $S D$ \\
\hline Less than 3 years (short) & $30(22.1 \%)$ & -0.11 & 1.17 & $6(4.4 \%)$ & 0.07 & 1.08 & $36(26.5 \%)$ & -0.08 & 1.14 \\
\hline From 3 to 9 years (middle) & $15(11.0 \%)$ & 0.87 & 0.52 & $8(5.9 \%)$ & 0.07 & 0.68 & $23(16.9 \%)$ & 0.59 & 0.68 \\
\hline More than 9 years (long) & $56(41.2 \%)$ & 0.29 & 1.06 & $21(15.4 \%)$ & 0.35 & 1.07 & $77(56.6 \%)$ & 0.30 & 1.06 \\
\hline Total & $101(74.3 \%)$ & 0.26 & 1.07 & $35(25.7 \%)$ & 0.24 & 0.98 & $136(100 \%)$ & 0.25 & 1.05 \\
\hline
\end{tabular}

The complete linear model results, which include all the considered explanatory variables, are summarised in Table 3. It showed estimated regression coefficients (Beta), standardised regression coefficients (StBeta), related $95 \%$ confidence intervals (CI) and $t$-tests for regression coefficients and overall $F$-test for a subset of explanatory variables. As Table 3 shows, the degree of identification generally depends on the transformational style $(p<0.001)$ and the employment length $(p=$ $0.005)$. However, there was a relatively high inter-correlation of the included variables in the range of $0.55-0.80$. This is consistent with findings in Avolio and Bass (2004) that the transformational leadership substyles are usually highly correlated because they all represent the same category of behaviour based on the mutual reinforcement of its components.
Since this multi-collinearity may distort the regression analysis result, the superfluous variables were removed using stepwise regression. The final model was a sub-model of the complete model ( $F$-test for the sub-model: $p=0.829$ ). It included only five predictors: employment length, department type, inspirational motivation and intellectual stimulation (transformational leadership substyles) and passive laissez-faire style (Table 4). However, among the leadership substyles, only inspirational motivation had a positive effect on the identification degree.

Physicians and nurses have one main goal, and that is to provide care for their patients at the best possible level and to improve their health condition. They should form "one team" and work together to achieve the highest level of care and

Table 3. Regression analysis results for a complete model

\begin{tabular}{|c|c|c|c|c|c|}
\hline Explanatory variable & Beta & StBeta & $\begin{array}{r}95 \% \text { CI } \\
\text { for Beta } \\
\end{array}$ & $\begin{array}{c}t \text {-test } \\
p \text {-value }\end{array}$ & $\begin{array}{c}F \text {-test } \\
p \text {-value }\end{array}$ \\
\hline Employment-Middle & 0.772 & 0.278 & $(0.252,1.293)$ & 0.004 & \multirow{2}{*}{0.005} \\
\hline Employment-Long & 0.555 & 0.264 & $(0.163,0.947)$ & 0.006 & \\
\hline Department type-Inpatient & 0.374 & 0.157 & $(-0.033,0.781)$ & 0.071 & 0.071 \\
\hline Idealised influence (attributed) & 0.182 & 0.170 & $(-0.145,0.510)$ & 0.272 & \multirow{5}{*}{$<0.001$} \\
\hline Idealised influence (behaviour) & -0.030 & -0.024 & $(-0.409,0.349)$ & 0.875 & \\
\hline Inspirational motivation & 0.665 & 0.561 & $(0.262,1.068)$ & 0.001 & \\
\hline Intellectual stimulation & -0.314 & -0.274 & $(-0.644,0.017)$ & 0.063 & \\
\hline Individual consideration & -0.079 & -0.080 & $(-0.373,0.215)$ & 0.595 & \\
\hline Contingent reward & -0.190 & -0.169 & $(-0.545,0.165)$ & 0.292 & \multirow{2}{*}{0.531} \\
\hline Management-by-except. (active) & -0.056 & -0.044 & $(-0.331,0.219)$ & 0.688 & \\
\hline Management-by-except. (passive) & -0.011 & -0.009 & $(-0.251,0.229)$ & 0.929 & \multirow{2}{*}{0.270} \\
\hline Laissez-faire & -0.160 & -0.161 & $(-0.393,0.072)$ & 0.174 & \\
\hline
\end{tabular}

Multiple $R^{2}=0.249 ;$ Adjusted $R^{2}=0.175$; overall F-test model: $p<0.001$. 
Table 4. Regression analysis results for the final model

\begin{tabular}{|c|c|c|c|c|c|}
\hline Explanatory variable & Beta & StBeta & $\begin{array}{l}95 \% \text { CI } \\
\text { for Beta }\end{array}$ & $\begin{array}{c}t \text {-test } \\
p \text {-value }\end{array}$ & $\begin{array}{c}F \text {-test } \\
p \text {-value }\end{array}$ \\
\hline Employment-Middle & 0.747 & 0.268 & $(0.245,1.248)$ & 0.004 & \multirow{2}{*}{0.006} \\
\hline Employment-Long & 0.536 & 0.255 & $(0.153,0.919)$ & 0.006 & \\
\hline Department type-Inpatient & 0.371 & 0.155 & $(-0.015,0.757)$ & 0.059 & 0.059 \\
\hline Inspirational motivation & 0.614 & 0.518 & $(0.352,0.876)$ & $<0.001$ & \multirow{2}{*}{$<0.001$} \\
\hline Intellectual stimulation & -0.401 & -0.350 & $(-0.649,-0.153)$ & 0.002 & \\
\hline Laissez-faire & -0.161 & -0.162 & $(-0.348,0.025)$ & 0.089 & 0.089 \\
\hline
\end{tabular}

patients' recovery. However, in the Czech hospital environment, the demonstration of supremacy by physicians/superiors towards nurses is still prevalent (Bártlová et al., 2010). This was also reflected in the results of our research.

The most perceived leadership style was the transactional one, which consists of continuous monitoring of the subordinates' activities, controlling them and ensuring the achievement of the assigned tasks. The respondents mostly experienced from their superiors the approach based on the management-by-exception (active) substyle. Its main feature is the aim to catch the problem before it arises, which is not surprising if we take into account the character of work in healthcare. We can assume that the provision of healthcare creates an environment suitable for the development of the role culture (Handy, 1981), which can be characterised by clearly defined positions arising from the division of labour and the expertise of employees. Hospital managers work with a generally accepted and expanded assumption that strict standards and processes need to be followed. And not just in hospital departments where it is desirable to adhere to exact procedures, but elsewhere too. This is common even in situations where medical staff could have free space for their own way of solving the work tasks. However, as demonstrated by the results of our pilot study (Bednářová and Komárková, 2017), employees' job satisfaction is higher when their working conditions provide some degree of autonomy and opportunities for creative work. Therefore, if the nature of the work and work task allows, supervisors should enable staff to actively participate in task solutions.

We can support this idea with the fact that idealised influence (behaviour) and intellectual stimulation were also among the most perceived leadership substyles, although they belong to the transformational style, which is a counterpart to the transactional style and consists of transforming the needs of the subordinates and stimulating them. Idealised influence (behaviour) points to a strong perception of charismatic leadership and intellectual stimulation to enable self-realisation. The laissez-faire substyle has the smallest representation in the investigated hospital. Again, this is not surprising, since it is difficult to imagine a leader of a healthcare department who avoids decision-making and disclaims responsibility. Yet there were a few answers that indicated this might be perceived and this information should draw attention to the further investigation of this situation.

It can be summed up that there are two groups of managers in the examined hospital. The first group holds in its style the principle of clear superiority in terms of their position and does not give subordinate employees much space for self-realisation. Employees are forced to accept and obey orders be- cause they are in the role of subordinates. The second group shows signs of charismatic leaders who allow their subordinates some freedom and space for creativity. It is difficult to assess which is better if we do not know other contingencies, and we must admit that under specific healthcare conditions the transactional style may be effective.

Returning to our research questions, we can conclude that only the transformational leadership style has a statistically significant impact on nurses' identification with the hospital. While inspirational motivation increases organisational identification, intellectual stimulation has an adverse effect. Inspirational motivation develops teamwork based on trust, mutual understanding and support. We can assume that in working conditions where it is absolutely crucial to rely on each other, such an atmosphere of mutual support is an important source of satisfaction at work, commitment and identification with the organisation. On the other hand, the intellectual stimulation substyle is challenging and demanding; the leader expects initiative, critical and innovative thinking. He/she wants their staff to be able to function independently and not to rely on his/her support. In the healthcare environment, this may be taken as overloading or shifting responsibility to the subordinates and thus increasing the burden of work, which is already strongly demanding in its essence. And who would like to identify with the conditions that are the source of his/her nightmares?

A limitation of our study is the low return rate of questionnaires (less than 50\%). However, it is necessary to state that if the willingness to answer is not related to the studied issue, this does not cause bias in the results. The main reason for not filling out the questionnaire was the high workload of respondents. The leadership styles of the nurses' managers were investigated in only one hospital, so the results cannot reflect the situation in Czech healthcare as a whole. For future research, we plan a comparison of different types of hospitals, e.g. private hospitals or public hospitals (analogously as [Abdelhafiz et al., 2016] for Jordanian hospitals), or for-profit and non-profit orientation, respectively. It is obvious that different working conditions may call for different leadership styles, and the assessment of their appropriateness should be linked to other factors such as economic outcomes, commitment and employees' or patients' satisfaction.

\section{Conclusions}

From the point of view of the main purpose of the study, our findings on the interplay of the transformational style and the degree of organisational identification are very important. Es- 
pecially inspirational motivation has contributed positively to the degree of employees' identification. Leaders with these skills can attract and inspire. Therefore, such leaders represent a natural authority for employees, a solid point that can be leaned upon and relied on. However, it is not possible to regard the transformational style as a panacea for improving healthcare management. As shown in our results of the negative impact of intellectual stimulation on organisational identification, even a transformational leader must be able to reflect the contextual factors and to choose the appropriate tools for their management. We can conclude that followers inspired by a leader who is loyal to the organisation and clearly defines the vision can be taken as one of the most important factors that reinforce processes leading to the development of organisational identification and thus to better organisational effectiveness.

\section{Conflict of interests}

The authors have no conflict of interests to declare.

\section{Acknowledgement}

This paper was supported by the Czech Science Foundation (GA ČR) under the grant number 18-01159S.

\section{Styl vedení a jeho vliv na identifikaci zaměstnanců s organizací: studie z české nemocnice}

\section{Souhrn}

Lídři jsou v každodenním kontaktu s podřízenými zaměstnanci a svým stylem vedení ovlivňují chod organizace. Článek je zaměřen na zjištění toho, jak styl vedení v pojetí transformační teorie působí na identifikaci s organizací, tj. na důležitou a komplexní proměnnou, která hraje hlavní roli v efektivitě organizace. Dotazovaly jsme se vzorku zdravotních sester ze středně velké nemocnice, aby ohodnotily styl vedení vedoucích zdravotních sester a dále jejich vlastní identifikaci s nemocnicí. Ve studii byl využit kvantitativní výzkum založený na dotazníkovém šetření. První část zahrnovala Multifactor Leadership Questionnaire měříí styl vedení a jeho složky. Druhou část reprezentovala škála Maela a Ashfortha, která hodnotí míru identifikace zaměstnanců s organizací. Vztah mezi zvolenými proměnnými byl posuzován pomocí vícenásobné lineární regrese s délkou zaměstnání a typem oddělení v podobě kontrolních proměnných. Výsledky studie ukazují, že ve zvolené nemocnici mírně převažuje transakční styl vedení, ačkoliv pouze transformační styl a dvě jeho složky měly vliv na stupeň identifikace s organizací.

Klíčová slova: identifikace s organizací; management zdravotní péče; vedení lidí

\section{References}

1. Abdelhafiz IM, Alloubani AMD, Almatari M (2016). Impact of leadership styles adopted by head nurses on job satisfaction: a comparative study between governmental and private hospitals in Jordan. J Nurs Manag 24(3): 384-392. DOI: 10.1111/ jonm.12333.

2. AbuAlRub RF (2004). Job stress, job performance, and social support among hospital nurses. J Nurs Scholarsh 36(1): 73-78. DOI: 10.1111/j.1547-5069.2004.04016.x.

3. Albert S, Whetten DA (1985). Organizational identity. Research in organizational behaviour. In: Cummings LL, Staw MM, (Eds). Research in organizational behaviour: an annual series of analytical essays and critical reviews, volume 7 . Greenwich, CT: JAI Press.

4. Alloubani A (2016). Leadership styles and healthcare management in Jordan and worldwide. Noor Publishing.

5. Anderson MH, Sun PY (2017). Reviewing leadership styles: Overlaps and the need for a new 'full-range' theory. IJMR 19(1): 76-96. DOI: 10.1111/ijmr.12082.

6. Andrews DR, Richard DC, Robinson P, Celano P, Hallaron J (2012). The influence of staff nurse perception of leadership style on satisfaction with leadership: A cross-sectional survey of pediatric nurses. Int J Nurs Stud 49(9): 1103-1111. DOI: 10.1016/j.ijnurstu.2012.03.007.

7. Antonakis J, Avolio BJ, Sivasubramaniam N (2003). Context and leadership: An examination of the nine-factor fullrange leadership theory using the Multifactor Leadership Questionnaire. Leadersh Q 14(3): 261-295. DOI: 10.1016/ S10489843(03)00030-4.

8. Ashforth BE, Harrison SH, Corley KG (2008). Identification in organizations: An examination of four fundamental questions. J Manag 34(3): 325-374. DOI: 10.1177/0149206308316059.

9. Ashforth BE, Mael F (1989). Social identity theory and the organization. Acad Manage Rev 14(1): 20-39. DOI: 10.5465/ AMR.1989.4278999.
10. Avolio BJ, Bass BM (2004). Multifactor Leadership Questionnaire: Manual \& Review Copy. California: Mind Garden.

11. Avolio BJ, Walumbwa FO, Weber TJ (2009). Leadership: current theories, research, and future directions. Annu Rev Psychol 60(1): 421-449. DOI: 10.1146/annurev. psych.60.110707.163621.

12. Bakker AB, Le Blanc PM, Schaufeli WB (2005). Burnout contagion among intensive care nurses. J Adv Nurs 51(3): 276-287. DOI: 10.1111/j.1365-2648.2005.03494.x.

13. Bártlová S, Chloubová I, Trešlová M (2010). Vztah sestra-lékař. Národní centrum ošetřovatelství a nelékařských zdravotnických oborů.

14. Bass BM (1985). Leadership and performance beyond expectations. Collier Macmillan.

15. Bass BM, Avolio BJ, Jung DI, Berson Y (2003). Predicting unit performance by assessing transformational and transactional leadership. J Appl Psychol 88(2): 207-218. DOI: 10.1037/00219010.88.2.207.

16. Bednářová M, Komárková L (2017). Nurse Managers Leadership Styles: A Study from a Czech Profit-Oriented Hospital. In: Rich M (Ed.). Proceedings of the 13th European conference on management, leadership and governance. UK University of London, pp. 523-529.

17. Burns JM (1978). Leadership. New York: Harper and Row Publishers.

18. Chandra T, Priyono L (2016). The influence of leadership styles, work environment and job satisfaction of employee performance. IES 9(1): 131-140. DOI: 10.5539/ies.v9n1p131.

19. Cole MS, Bruch H (2006). Organizational identity strength, identification, and commitment and their relationships to turnover intention: Does organizational hierarchy matter? J Organiz Behav 27(5): 585-605. DOI: 10.1002/job.378.

20. Cooper D, Thatcher SM (2010). Identification in organizations: The role of self-concept orientations and identification motives. Acad Manage Rev 35(4): 516-538. DOI: 10.5465/ amr.35.4.zok516. 
21. Delić A, Kozarević E, Alić M (2017). Impact of leadership style on bank profitability: Case study of a bank in Bosnia and Herzegovina. Management: Journal of Contemporary Management Issues 22(2): 65-77. DOI: 10.30924/ $\mathrm{mjcmi} / 2017.22 .2 .65$.

22. Dinh JE, Lord RG, Gardner WL, Meuser JD, Liden RC, Hu J (2013). Leadership theory and research in the new millennium: Current theoretical trends and changing perspectives. Leadersh Q 25(1): 36-62. DOI: 10.1016/j.leaqua.2013.11.005.

23. DuBrin AJ (2016). Leadership: Research findings, practice, and skills. Boston, MA: Cengage Learning.

24. Dutton JE, Dukerich JM, Harquail CV (1994). Organizational images and member identification. Adm Sci Q 39(2): 239-263. DOI: $10.2307 / 2393235$

25. Failla K, Stichler J (2008). Manager and staff perceptions of the manager's leadership style. J Nurs Adm 38(11): 480-487. DOI: 10.1097/01.NNA.0000339472.19725.31.

26. Fiol CM, O'Connor EJ (2005). Identification in face-to-face, hybrid, and pure virtual teams: Untangling the contradictions. Organ Sci 16(1): 19-32. DOI: 10.1287/orsc.1040.0101.

27. Fuchs S (2012). Understanding psychological bonds between individuals and organizations: The coalescence model of organizational identification. UK: Palgrave Macmillan. DOI: $10.1057 / 9781137033970$.

28. Gilmartin MJ, D’Aunno TA (2007). Leadership research in healthcare: a review and roadmap. Acad Manag Ann 1(1): 387-438. DOI: 10.1080/078559813.

29. Glamuzina M (2015). Levels of leadership development and top management's effectiveness: Is there a clear-cut relationship? Management: Journal of Contemporary Management Issues 20(Special issue): 89-131.

30. Gulavani A, Shinde MB (2014). Occupational stress and job satisfaction among nurses. IJSR 3(4): 733-740.

31. Handy CB (1981). Understanding Organisations. Harmondsworth: Penguin Books.

32. Haslam SA (2004). Psychology in organizations. Sage Publications.

33. Haslam SA, Ellemers N (2005). Social identity in industrial and organizational psychology: Concepts, controversies and contributions. IJIO 20(1): 39-118. DOI: 10.1002/0470029307. ch2.

34. Healy S, Tyrrell M (2011). Stress in emergency departments: Experiences of nurses and doctors. Emergency Nurse 19(4): 31-37. DOI: 10.7748/en2011.07.19.4.31.c8611.

35. Holdren P, Paul DP, Coustasse A (2015). Burnout syndrome in hospital nurses. Paper presented at BHAA International 2015 in Chicago, IL.

36. Huber D (2010). Leadership and Nursing Care Management. Philadelphia, PA: WB Saunders.

37. Jarošová D (2006). Základy managementu v ošetřovatelství. Ostrava: Ostravská univerzita. [online] [cit. 2018-0920]. Available from: http://projekty.osu.cz/mentor/IImanagement\%20v\%20osetrovatelstvi.pdf

38. Judge TA, Piccolo RF (2004). Transformational and transactional leadership: a meta-analytic test of their relative validity. J Appl Psychol 89(5): 755-768. DOI: 10.1037/00219010.89.5.755

39. Karadağ E (Ed.) (2015). Leadership and organizational outcomes: Meta-analysis of empirical studies. Springer.

40. Kirkbride P (2006). Developing transformational leaders: the full range leadership model in action. Ind Commerc Train 38(1): 23-32. DOI: 10.1108/00197850610646016.

41. Lee ES, Park TY, Koo B (2015). Identifying organizational identification as a basis for attitudes and behaviors: A metaanalytic review. Psychol Bull 141(5): 1049-1080. DOI: 10.1037/ bul0000012.
42. Lowe KB, Gardner WL (2000). Ten years of the leadership quarterly: Contributions and challenges for the future. Leadersh Q 11(4): 459-514. DOI: 10.1016/S1048-9843(00)00059-X.

43. Mael F, Ashforth BE (1992). Alumni and their alma mater: A partial test of the reformulated model of organizational identification. J Organ Behav 13(2): 103-123. DOI: 10.1002/ job.4030130202.

44. Millward LJ, Postmes T (2010). Who we are affects how we do: The financial benefits of organizational identification. Br J Manag 21(2): 327-339. DOI: 10.1111/j.14678551.2009.00667.x.

45. Moksness L (2014). Verbal measure, or graphic measure, or both? Psychometric study of organizational identification. Master's thesis, UiT Norway's Arctic University.

46. Morsiani G, Bagnasco A, Sasso L (2017). How staff nurses perceive the impact of nurse managers' leadership style in terms of job satisfaction: a mixed method study. J Nurs Manag 25(2): 119-128. DOI: 10.1111/jonm.12448.

47. Northouse PG (2016). Leadership: Theory and practice. Los Angeles, CA: Sage publications.

48. Patchen M (1970). Participation, achievement, and involvement on the job. New Jersey: Prentice-Hall.

49. Procházka J, Vaculík M (2015). Transformační vedení: „Normativní" psychologická teorie efektivního vedení lidí. Československá psychologie 59(2): 137-149.

50. R Core Team (2018). R: A language and environment for statistical computing. R Foundation for Statistical Computing, Vienna, Austria. [online] [cit. 2018-09-03]. Available from: https://www.gbif.org/tool/81287/r-a-language-andenvironment-for-statistical-computing

51. Riketta M (2005). Organizational identification: A metaanalysis. J Vocat Behav 66(2): 358-384. DOI: 10.1016/j. jvb.2004.05.005.

52. Riketta M, Van Dick R (2005). Foci of attachment in organizations: A meta-analytic comparison of the strength and correlates of workgroup versus organizational identification and commitment. J Vocat Behav 67(3): 490-510. DOI: 10.1016/j. jvb.2004.06.001.

53. Stogdill RM (1974). Handbook of leadership: A survey of theory and research. New York, NY: Free Press.

54. Tummers LG, Knies E (2013). Leadership and meaningful work in the public sector. Public Adm Rev 73(6): 859-868. DOI: 10.1111/puar.12138.

55. Tyler TR, Blader SL (2001). Identity and cooperative behavior in groups. Group Process Intergroup Relat 4(3): 207-226. DOI: $10.1177 / 1368430201004003003$.

56. Wang G, Oh IS, Courtright SH, Colbert AE (2001). Transformational leadership and performance across criteria and levels: A meta-analytic review of 25 years of research. Group Organ Manag 36(2): 223-270. DOI: $10.1177 / 1059601111401017$.

57. Weng RH, Huang CY, Chen LM, Chang LY (2015). Exploring the impact of transformational leadership on nurse innovation behaviour: A cross-sectional study. J Nurs Manag 23(4): 427-439. DOI: 10.1111/jonm.12149.

58. Wong CA, Cummings GG, Ducharme L (2013). The relationship between nursing leadership and patient outcomes: a systematic review update. J Nurs Manag 21(5): 709-724. DOI: 10.1111/ jonm.12116.

59. Yukl G (2008). How leaders influence organizational effectiveness. Leadersh Q 19(6): 708-722. DOI: 10.1016/j. leaqua.2008.09.008. 